\title{
Green manures and poultry feather effects on soil characteristics, growth, yield, and mineral contents of tomato
}

\author{
Aruna Olasekan Adekiya \\ College of Agricultural Sciences, Landmark University, Omu-Aran, Kwara State, Nigeria
}

\section{A R T I C L E I N F O}

\section{Keywords:}

Banana leaves

Tithonia diversifolia

Poultry feather

Tomato

Yield

Mineral content

\begin{abstract}
A B S T R A C T
Organic amendments are relatively cheap and available source of organic matter for sustaining both the physical and chemical soil characteristics, and crop yield. Therefore, two field experiments were conducted in 2017 and 2018 to determine the sole and combined effects of Tithonia diversifolia and banana leaves, and poultry feather (PF) on soil characteristics, growth, yield, and mineral contents of tomato (Solanum lycopersicum L.). The treatments were: (i). Tithonia leaves alone applied at $10.0 \mathrm{t} \mathrm{ha}^{-1}$, (ii). Banana leaves alone applied at $10.0 \mathrm{t}$ $\mathrm{ha}^{-1}$, (iii). Crushed PF alone applied at $10.0 \mathrm{t} \mathrm{ha}^{-1}$, (iv). PF at $5.0 \mathrm{t} \mathrm{ha}^{-1}+$ banana leaves at $5.0 \mathrm{t} \mathrm{ha}^{-1},(\mathrm{v}) . \mathrm{PF}$ at $5.0 \mathrm{t} \mathrm{ha}^{-1}+$ Tithonia leaves at $5.0 \mathrm{t} \mathrm{ha}^{-1}$, (vi). Tithonia leaves at $5.0 \mathrm{tha}^{-1}+$ Banana leaves at $5.0 \mathrm{tha}^{-1}$, and (vii). Control - no amendment. The seven treatments were arranged in a randomized complete block design with three replications. Green manures and PF either sole or combined significantly $(\mathrm{p}<0.05)$ reduced soil bulk density and increased porosity, soil organic matter (SOM), nutrient contents, growth, yield, and mineral contents of tomato crop compared with the control. When manures were combined, PF + Tithonia has the highest value of these parameters. PF + Tithonia increased tomato yield by 20.0, 53.0, 77.0 and 132.5\%, respectively compared with feather alone, Tithonia alone, banana alone and the control for year 2017, and by 28.3, 59.2, 73.0, and $237.3 \%$, respectively for year 2018. The increased growth, yield, and mineral contents of tomato under PF + Tithonia was due to improved soil physical and chemical properties and also due to the fact that slowly decaying poultry feather may allow retention of released nutrients from rapidly decomposing Tithonia within the rooting zone, thereby fostering greater efficiency of nutrient release and uptake. Therefore, locally sourced organic material can be used in improving soil and crop productivity especially when they are combined.
\end{abstract}

\section{Introduction}

Decline in soil fertility is one of the major factors affecting crop production in tropical countries. The soils tend to be highly weathered with low organic matter and nutrient retention capacity. Due to high rainfall, most of the mineral elements are leached away. In Nigeria, the most important soil order - Alfisols have weak structures and are highly susceptible to crusting, compaction, and erosion (Lal, 1987) leading to low crop yield. Chemical fertilizers can be used for improving soil fertility and crop yield, but their use especially in Nigeria is limited by scarcity and cost. Other problems associated with the use of chemical fertilizers are acidity, nutrient imbalance, (Agbede et al., 2018) and inability to improve aggregate stability by increasing soil organic matter. Organic amendments can be a cheap and readily available source of organic matter for sustaining both the physical and chemical soil characteristics and crop yield.

Mexican sunflower (Tithonia diversifolia) and Banana (Musa spp) leaves as green manures and farm waste such as poultry feather are areas that have not been fully exploited in soil fertility maintenance and crop yield improvement.

Banana plant is a tree like herb that belongs to the family of Musaceae. All aerial parts of the plant are usually known as corm (Stover and Simmonds, 1987). They are usually between 5-7 m tall depending on varieties (Nelson et al., 2006), leaves are spirally arranged, and large - about $2.7 \mathrm{~m}$ long and $60 \mathrm{~cm}$ wide (Morton, 1987). At harvest of banana fruits, the aerial parts especially the large leaves with high nutrient contents are usually abandoned (Mawahib et al., 2015). Doran and Kaya (2003) also reported that banana leaves contain many nutrients such as $\mathrm{N}, \mathrm{P}, \mathrm{K}, \mathrm{Ca}$ and $\mathrm{Mg}$.

Mexican sunflower (Tithonia diversifolia) is a shrub that belongs to the family Asteraceae. The shrub according to Sonke (1997) is everywhere in humid and sub-humid tropics. In southwest Nigeria, it grows luxuriantly along roads and fallow lands. It was reported that it has high decomposition rate and high concentration of N, P, and K (Jama et al., 2000; Gachengo et al., 1999). However, research information on the use of Tithonia as green manure for tomato production on Alfisol of

E-mail address: adekiya2009@yahoo.com. 
southwest Nigeria is very rear. There is the need to look at how this weed species could be used as green manure for soil fertility restoration and performance of tomato.

In Nigeria, the introduction of commercial poultry production over the years has caused an increase in the industry (Adene, 1997), which has resulted in the increase in poultry wastes. Poultry feather is one of the important waste from poultry slaughter houses. Grazziotin et al. (2006) reported that feather is about $10 \%$ of the total weight of a poultry. Though, poultry feathers are abundant in poultry slaughter houses causing offensive odours and inviting flies, nothing had been done about researching into its potential in soil fertility improvement. According to Hartz and Johnstone (2006) poultry feather could be a cheap source of organic fertilizer for crop production, for it contains $\mathrm{N}$, $\mathrm{P}$, and $\mathrm{K}$.

The quality of an applied organic amendment to the soil is determined by the nature and the chemical compositions of the amendment among other things (Adekiya, 2018). Each amendment applied to the soil may not contain all required nutrients in high amount at the same time. Therefore, to have a balanced nutrient supply, addition of more than one amendment to the soil may be required. Adekiya (2018) in an experiment carried out at Owo, forest - savannah transition zone of southwest Nigeria, found that addition of poultry manure with Leucaena, Gliricidia, and Acacia used as mulches significantly increased the soil nutrient, growth, and yield of tomato (Solanum lycopersicum L.) compared with their sole form. Aboyeji et al. (2019) also found that application of $25 \%$ Parkia and $75 \%$ Tithonia leaves as green manure increased the yield of radish (Raphanus sativus L.) compared to $100 \%$ Parkia leaves at Omu- Aran, derived savannah ecological zone of Nigeria. It is therefore necessary to determine the benefit derivable from the addition of two amendments in order to improve soil physical and chemical characteristics, and crop growth, yield, and mineral contents of crops. Therefore, the objectives of this study were to determine the sole and combined effects of Tithonia diversifolia, Banana leaves, and poultry feather on soil characteristics, growth, yield, and mineral contents of tomato. Based on these objectives, it was hypothesized that soil characteristics, growth, yield, and mineral content of tomato would react differently to sole and combined application green manures and poultry feather. Studies were therefore conducted to validate this hypothesis.

\section{Materials and methods}

\subsection{Site description and experimental layout}

Two field experiments were conducted at Owo (Latitude $7^{\circ} 12{ }^{`} \mathrm{~N}$ and Longitude $5^{\circ} 32{ }^{`} \mathrm{E}$ and is $348 \mathrm{~m}$ above sea level) Ondo State Nigeria in 2017 and 2018. The soil at Owo is an Alfisol or Luvisol. Owo experiences rainfall distribution that ranges between $1240-1346 \mathrm{~mm}$ with air temperature that ranges between $24-31{ }^{\circ} \mathrm{C}$. It is located in a forest savanna transition zone. The area has two rainy seasons, from March to July, and the other from September to November. The site was mechanically cleared from a one year old fallow after continuous cropping of maize (Zea mays L.) and cassava (Manihot esculenta Crantz) for three years. The experiment each year (2017 \& 2018) consisted of two plants [Mexican sunflower: Tithonia diversifolia Asteraceae, and Banana: Musa spp] leaves applied as green manure, and poultry feather incorporated into the soil. The treatments were: (i). Tithonia leaves alone applied the rate of $10.0 \mathrm{tha}^{-1}$, (ii). Banana leaves alone applied at the rate of $10.0 \mathrm{t}$ $\mathrm{ha}^{-1}$, (iii). Crushed poultry feather alone applied at the rate of $10.0 \mathrm{tha}^{-}$ ${ }^{1}$, (iv). Poultry feather at $5.0 \mathrm{t} \mathrm{ha}^{-1}+$ banana leaves at $5.0 \mathrm{t} \mathrm{ha}^{-1}$, (v). Poultry feather at $5.0 \mathrm{t} \mathrm{ha}^{-1}+$ Tithonia leaves at $5.0 \mathrm{t} \mathrm{ha}^{-1}$, (vi). Tithonia leaves at 5.0 tha $^{-1}+$ Banana leaves at $5.0 \mathrm{t} \mathrm{ha}^{-1}$, and (vii) Control - no amendment of any kind. The seven treatments were arranged in a randomized complete block design with three replications. Each block consisted of 7 plots measuring $3 \times 2 \mathrm{~m}$ with $1 \mathrm{~m}$ block and $0.5 \mathrm{~m}$ between plots

\subsection{Incorporation of poultry feather and green manures and planting of tomato}

The poultry feather used were collected from chicken (broiler) slaughter house, washed, dried, and crushed by a mill. The Tithonia leaves were collected from nearby bushes while the banana leaves were collected from a banana farm where banana fruits had just been harvested. Fresh leaves of both Tithonia and banana leaves were chopped before incorporation. Ploughing and harrowing of the site to be used were done in May each year, thereafter the land was laid out to $3 \times 2 \mathrm{~m}$ plot sizes. A hand-held hoe was used to incorporate the green manures and poultry feather into the soil to a depth of approximately $20 \mathrm{~cm}$. The plots were allowed for 4 week before transplanting of tomato. Prior to land preparation (in April) of each year, tomato (Solanum lycopersicum L.) seeds (Owo local variety) treated with a seed-dressing fungicide (Apron plus 50 DS) against seed-borne or soil-borne pathogens were sown into a rich loamy soil in raised beds in the nursery under a shade at a temperature of about $23^{\circ} \mathrm{C}$ and watered daily in the evening using a watering can to field capacity. After 3 weeks in the nursery, the shade in the nursery was removed to harden the plants. The seedlings were allowed 4 weeks in the nursery before transplanting. At transplanting, which was done in the evening, seedlings were transplanted with ball of earth to reduce damage to the roots. One tomato seedling was transplanted per hole with a spacing of $50 \times 50 \mathrm{~cm}$ to give a plant population of 12 plants per plot. Three manual weedings were done at 2, 5, and 8 weeks after transplanting (WAT). Tomato plant were staked at 5 WAT.

\subsection{Determination of soil properties}

In 2017 before the start of the experiment, soil samples from 0 $0.15 \mathrm{~m}$ depth were randomly collected from 10 points from the experimental site. The soil samples were bulk together, air - dried, and sieved with $2 \mathrm{~mm}$ sieve for analysis (to serve as composite soil sample). The hydrometer method was used for the determination of particle size (Gee and Or, 2002). Also, before the start of the experiment, bulk density of the experimental site was determined using the method of Campbell and Henshall (1991). Soil organic carbon (OC) was determined by the procedure of Walkley and Black using the dichromate wet oxidation method (Nelson and Sommers, 1996). Organic matter (OM) was calculated by multiplying $\mathrm{C}$ by 1.724 . Total $\mathrm{N}$ was determined by the micro-Kjeldahl digestion method (Bremner, 1996). Available $\mathrm{P}$ was determined by Bray-1 extraction followed by molybdenum blue colorimetry (Frank et al., 1998). Exchangeable K, Ca, and $\mathrm{Mg}$ were extracted using $1 \mathrm{M}$ ammonium acetate (Hendershot et al., 2007). Thereafter, concentration of $\mathrm{K}$ was determined on a flame photometer, and $\mathrm{Ca}$ and $\mathrm{Mg}$ were determined by EDTA titration method. Soil $\mathrm{pH}$ was determined using a soil-water medium at a ratio of $1: 2$ with a digital electronic $\mathrm{pH}$ meter. At the end of each year's experiment, soil samples were also collected on plot basis (with three samples from each plot and later bulked together) and similarly analyzed for soil chemical properties.

Two WAT of tomato seedlings, determination of bulk density in all plots was started and was repeated on 4 occasions at 4, 6, 8, and 12 WAT. Core samplers $(0.04 \mathrm{~m}$ diameter and $0.15 \mathrm{~m}$ high) in each occasion were used to collect soil sample from $0-0.15 \mathrm{~m}$ depth at about $0.1 \mathrm{~m}$ away from tomato plant. The soil samples were used to evaluate bulk density after oven drying at $100^{\circ} \mathrm{C}$ for $24 \mathrm{~h}$. soil porosity was calculated from the values of bulk density using the particle density value of $2.65 \mathrm{~g} \mathrm{~cm}^{-3}$.

\subsection{Determination of Growth and yield of tomato}

Six tomato plants were randomly selected per plot for the determination of growth parameters (plant height, leaf area, and number of leaves per plant) at mid flowering stage of tomato plant. Plant height 
was determined by measuring with a meter rule from the base to the shoot buds, number of leaves was by manual counting, and leaf area was calculated using the model $\left(\mathrm{A}=\mathrm{KL}^{2}\right)$ developed by Lyon (1948), where $\mathrm{L}=$ Length, $\mathrm{K}=$ constant which is 0.1551 , and $\mathrm{A}=$ leaf area. Tomato fruit yields were the weight of harvest from up to 100 days after transplanting.

\subsection{Analysis of tomato fruits, green manure and poultry feather}

Matured tomato fruits of uniform size were selected per plot at harvest each year for chemical analysis to determine their mineral compositions as described by AOAC (2006). One gram of each sample was digested using $12 \mathrm{~cm}^{-3}$ of the mix of $\mathrm{HNO}_{3}, \mathrm{H}_{2} \mathrm{SO}_{4}$ and $\mathrm{HCLO}_{4}$ $(7: 2: 1 \mathrm{v} / \mathrm{v} / \mathrm{v})$. Contents of $\mathrm{Cu}, \mathrm{Fe}, \mathrm{Mg}, \mathrm{K}$, and $\mathrm{Ca}$ were determined by atomic absorption spectrophotometry. Part of the green manures (Tithonia and banana leaves) and poultry feather to be incorporated into the soil were processed for chemical analysis. The fresh green manures were put in oven set at $70^{\circ} \mathrm{C}$ for $24 \mathrm{~h}$ and later grounded for analysis. Also, the washed, dried, and grounded poultry feather was sieved using $2 \mathrm{~mm}$ sieve ready for chemical analysis. The samples were analyzed for C, N, P, K, Ca, and Mg as described by Tel and Hagarty (1984).

\subsection{Statistical analysis}

Data collected from each experiment in both years were subjected to analysis of variance (two-ANOVA) using the Genstat statistical package (GENSTAT, 2005) and treatment means were compared using Duncan's multiple range test at $\mathrm{p}<0.05$ probability level.

\section{Results}

\subsection{Soil properties prior experimentation and analysis of green manure and poultry feather}

Tables 1 and 2 respectively showed the results of the soil of the site before experimentation and the chemical analysis of the green manures, and poultry feather. The soil of the site was sandy loamy, fairly high in bulk density, acidic, and low in $\mathrm{OM}, \mathrm{N}, \mathrm{P}, \mathrm{K}, \mathrm{Ca}$, and $\mathrm{Mg}$ according to the critical level of $3.0 \% \mathrm{OM}, 0.20 \% \mathrm{~N}, 10.0 \mathrm{mg} \mathrm{kg}^{1}{ }^{1}$ available $\mathrm{P}$, $0.16-0.20 \mathrm{cmol} \mathrm{kg}^{-1}$ exchangeable $\mathrm{K}, 2.0 \mathrm{cmol} \mathrm{kg}^{-1}$ exchangeable $\mathrm{Ca}$, and $0.40 \mathrm{cmol} \mathrm{kg}^{-1}$ exchangeable $\mathrm{Mg}$ recommended for crop production in ecological zones of Nigeria (Akinrinde and Obigbesan, 2000). The green manures (Tithonia and banana leaves) and poultry feather contained nutrient elements (Table 2). Poultry feather has significantly higher values of OC, N, P, and Mg whereas Tithonia has higher $\mathrm{K}, \mathrm{Ca}$, and lower $\mathrm{C}$ : $\mathrm{N}$ ratio. The order of $\mathrm{C}$ : $\mathrm{N}$ ratio was Banana $>$ poultry feather > Tithonia.

Table 1

Initial soil characteristics before experimentation.

\begin{tabular}{ll}
\hline Property & Value \\
\hline Sand (\%) & 66.3 \\
Silt (\%) & 17.1 \\
Clay (\%) & 16.6 \\
Textural class & Sandy loam \\
Bulk density $\left(\mathrm{Mg} \mathrm{m}^{-3}\right)$ & 1.50 \\
Porosity (\%) & 43.4 \\
Soil organic matter (\%) & 2.10 \\
pH (water) & 5.80 \\
Total N (\%) & 0.14 \\
Available P (mg kg & 9.20 \\
Exchangeable $\mathrm{K}\left(\mathrm{cmol} \mathrm{kg}^{-1}\right)$ & 0.14 \\
Exchangeable Ca $\left(\mathrm{cmol} \mathrm{kg}^{-1}\right)$ & 1.90 \\
Exchangeable $\mathrm{Mg}\left(\mathrm{cmol} \mathrm{kg}^{-1}\right)$ & 0.29 \\
\hline
\end{tabular}

Table 2

Chemical analysis of Tithonia and banana leaves and poultry feather used.

\begin{tabular}{llllllll}
\hline & OC (\%) & N (\%) & C: N & P (\%) & K (\%) & Ca (\%) & Mg (\%) \\
\hline Tithonia leaves & $28.6 \mathrm{a}$ & 3.75b & $7.63 \mathrm{c}$ & $0.39 \mathrm{~b}$ & $4.31 \mathrm{a}$ & $3.22 \mathrm{a}$ & $0.08 \mathrm{c}$ \\
Banana leaves & $27.4 \mathrm{~b}$ & $1.40 \mathrm{c}$ & $19.57 \mathrm{a}$ & $0.22 \mathrm{c}$ & $0.96 \mathrm{~b}$ & $0.51 \mathrm{c}$ & $0.42 \mathrm{~b}$ \\
Poultry Feather & $41.6 \mathrm{c}$ & $4.28 \mathrm{a}$ & $9.72 \mathrm{~b}$ & $0.61 \mathrm{a}$ & $0.99 \mathrm{~b}$ & $0.76 \mathrm{~b}$ & $0.81 \mathrm{a}$
\end{tabular}

Values followed by similar letters under the same column are not significantly different at $\mathrm{p}=0.05$ according to Duncan's multiple range test.

\subsection{Effect of green manures and poultry feather on soil properties}

Data on the effect of green manure and poultry feather on soil chemical and physical properties in years 2017 and 2018 are presented in Table 3. There were no significant differences in the values of soil $\mathrm{pH}$ and $\mathrm{Mg}$ between years 2017 and 2018. Year 2018 had lower bulk density, higher values of porosity, OM, N, P, K, and Ca compared with year 2017. All soil amendments increase soil chemical properties and porosity, and reduced bulk density compared with the control. Poultry feather alone had the highest value of soil $\mathrm{pH}$. Poultry feather $+\mathrm{Ti}$ thonia had the highest values of $\mathrm{N}, \mathrm{P}, \mathrm{K} \mathrm{Ca}$, and $\mathrm{Mg}$. There were no significant differences in $\mathrm{N}, \mathrm{P}$, and Ca values between poultry feather alone and poultry feather + Tithonia. Also, poultry feather + Tithonia had the highest value of SOM. Among poultry feather, Tithonia, and banana applied alone, poultry feather had the lowest bulk density and highest porosity. Treatments where amendments were combined had higher porosity and lower bulk density values compared with their sole forms. The interactive effect of year $(\mathrm{Y})$ and amendment $(\mathrm{A})(\mathrm{Y} \times \mathrm{A})$ was significant for OM, N, P, K, Ca, bulk density, and porosity, but not significant for $\mathrm{pH}$ and $\mathrm{Mg}$.

\subsection{Effect of green manures and poultry feather on growth and yield of tomato}

The results of the effect of green manures and poultry feather on yield of tomato, plant height, leaf area, and number of leaves are respectively presented in Fig. 1 a, b, c, and d. Year 2018 produced significantly higher values of tomato growth and yield compared with year 2017. By averaging 2017 and 2018, year 2018 increased fruit yield of tomato by 0.76 tonnes or $5.6 \%$ compared with 2017 . All forms of incorporated soil amendment increased fruit yield of tomato, plant height, leaf area per plant, and number of leaves per plant relative to the control. Among sole forms of amendment, poultry feather significantly increased growth and yield parameters compared with Tithonia and banana. In all, poultry feather + Tithonia has the highest value. Poultry feather + Tithonia increased tomato yield by $3.0,6.2$, 7.8 , and 10.2 tonnes, translating to $20.0,53.0,77.0$, and $132.5 \%$, respectively compared with poultry feather alone, Tithonia alone, banana alone, and the control for year 2017 and increased tomato yield by 4.4 , 7.4, 8.4, and 14.0 tonnes, translating to $28.3,59.2,73.0$, and $237.3 \%$, respectively compared with feather alone, Tithonia alone, banana alone, and the control for year 2018. Likewise, poultry feather + Tithonia increased plant height of tomato by 63.3, 151.0, 237.9 and $345.0 \%$, respectively compared with feather alone, Tithonia alone, banana alone and the control for year 2017 and by 79.1, 166.6, 252.9, and 500.0\%, respectively for year 2018. The interactive effect of $\mathrm{Y} \times \mathrm{A}$ was significant for growth and yield parameters.

\subsection{Effect of green manures and poultry feather on mineral contents of tomato fruit}

Year 2018 increased significantly Ca, K, Fe, and Mg content of tomato fruit compared with year 2017 (Table 4). The value of $\mathrm{Cu}$ between 2017 and 2018 was not significant. Also, amendments improved mineral contents of tomato fruit compared with the control. Cu was not 
Table 3

Effect of Green manures and poultry feather on growth and yield of tomato in 2017 \& 2018 .

\begin{tabular}{|c|c|c|c|c|c|c|c|c|c|c|}
\hline Year & Amendment & $\mathrm{pH}$ (water) & OM (\%) & N (\%) & $\mathrm{P}\left(\mathrm{mg} \mathrm{kg}^{-1}\right)$ & $\mathrm{K}\left(\mathrm{cmol} \mathrm{kg}^{-1}\right)$ & $\mathrm{Ca}\left(\mathrm{cmol} \mathrm{kg}^{-1}\right)$ & $\mathrm{Mg}\left(\mathrm{cmol} \mathrm{kg}^{-1}\right)$ & Bulk density $\left(\mathrm{Mg} \mathrm{m}^{-3}\right)$ & Porosity (\%) \\
\hline \multirow[t]{7}{*}{2017} & Control & $5.77 \mathrm{~b}$ & $1.78 \mathrm{f}$ & $0.12 \mathrm{f}$ & $8.9 \mathrm{~d}$ & $0.11 \mathrm{~g}$ & $1.74 \mathrm{e}$ & $0.27 \mathrm{f}$ & $1.51 \mathrm{a}$ & 43.01d \\
\hline & Tithonia & $5.54 \mathrm{c}$ & $2.82 \mathrm{c}$ & $0.22 \mathrm{~d}$ & $12.3 \mathrm{~b}$ & $0.27 \mathrm{~b}$ & $2.24 \mathrm{c}$ & $0.44 d$ & $1.21 \mathrm{~b}$ & $54.34 \mathrm{c}$ \\
\hline & Banana & $5.57 \mathrm{c}$ & $2.70 \mathrm{~d}$ & $0.19 \mathrm{e}$ & $11.0 \mathrm{c}$ & $0.17 \mathrm{de}$ & $2.06 \mathrm{~d}$ & $0.40 \mathrm{e}$ & $1.22 \mathrm{~b}$ & $53.96 c$ \\
\hline & $\mathrm{PF}$ & $5.90 \mathrm{a}$ & $2.54 \mathrm{e}$ & $0.28 \mathrm{a}$ & $14.7 \mathrm{a}$ & $0.16 \mathrm{e}$ & $2.45 \mathrm{a}$ & $0.33 \mathrm{f}$ & $1.19 \mathrm{c}$ & $55.09 \mathrm{~b}$ \\
\hline & $\mathrm{PF}+$ banana & $5.63 c$ & $2.90 \mathrm{~b}$ & $0.23 c d$ & $12.1 \mathrm{~b}$ & $0.12 \mathrm{f}$ & $2.38 \mathrm{~b}$ & $0.65 c$ & $1.14 \mathrm{~d}$ & $56.98 \mathrm{a}$ \\
\hline & $\mathrm{PF}+$ Tithonia & $5.60 c$ & $3.20 \mathrm{a}$ & $0.28 \mathrm{a}$ & $14.8 \mathrm{a}$ & $0.30 \mathrm{a}$ & $2.50 \mathrm{a}$ & $0.89 a$ & $1.11 \mathrm{~d}$ & $58.11 \mathrm{a}$ \\
\hline & Tithonia + banana & $5.52 c$ & $3.15 \mathrm{a}$ & $0.27 b$ & $12.6 \mathrm{~b}$ & $0.21 \mathrm{c}$ & $2.26 \mathrm{c}$ & $0.74 b$ & $1.13 \mathrm{~d}$ & $57.36 \mathrm{a}$ \\
\hline \multirow[t]{10}{*}{2018} & Control & $5.70 \mathrm{~b}$ & $1.71 \mathrm{f}$ & $0.10 \mathrm{e}$ & $8.7 d$ & $0.10 \mathrm{~g}$ & $1.60 \mathrm{e}$ & $0.22 \mathrm{f}$ & $1.52 \mathrm{a}$ & $42.64 d$ \\
\hline & Tithonia & $5.53 c$ & $3.01 \mathrm{c}$ & $0.24 \mathrm{c}$ & $13.4 \mathrm{~b}$ & $0.30 \mathrm{~b}$ & $2.32 \mathrm{c}$ & $0.44 d$ & $1.18 \mathrm{~b}$ & $55.47 \mathrm{c}$ \\
\hline & Banana & $5.55 c$ & $2.96 \mathrm{~d}$ & $0.21 \mathrm{~d}$ & $12.6 \mathrm{c}$ & $0.20 \mathrm{de}$ & $2.12 \mathrm{~d}$ & $0.41 \mathrm{e}$ & $1.19 \mathrm{~b}$ & $55.09 c$ \\
\hline & $\mathrm{PF}$ & $5.87 \mathrm{a}$ & $2.73 \mathrm{e}$ & $0.30 \mathrm{ab}$ & $15.5 \mathrm{a}$ & $0.19 \mathrm{e}$ & $2.60 \mathrm{a}$ & $0.34 \mathrm{f}$ & $1.17 \mathrm{c}$ & $55.85 \mathrm{~b}$ \\
\hline & $\mathrm{PF}+$ banana & $5.60 c$ & $3.21 b$ & $0.24 \mathrm{c}$ & $13.2 \mathrm{~b}$ & $0.13 \mathrm{f}$ & $2.46 \mathrm{~b}$ & $0.66 \mathrm{c}$ & $1.09 \mathrm{~d}$ & $58.87 \mathrm{a}$ \\
\hline & $\mathrm{PF}+$ Tithonia & $5.60 c$ & $3.48 \mathrm{a}$ & $0.32 \mathrm{a}$ & $15.9 \mathrm{a}$ & $0.35 a$ & $2.65 \mathrm{a}$ & $0.91 \mathrm{a}$ & $1.04 \mathrm{~d}$ & $60.75 a$ \\
\hline & Tithonia + banana & $5.50 \mathrm{c}$ & $3.41 \mathrm{a}$ & $0.29 b$ & $13.8 \mathrm{~b}$ & $0.24 \mathrm{c}$ & $2.34 \mathrm{c}$ & $0.75 b$ & $1.08 \mathrm{~d}$ & $59.25 a$ \\
\hline & Year $(Y)$ & $\mathrm{ns}$ & $*$ & $*$ & $*$ & $*$ & $*$ & Ns & * & $*$ \\
\hline & Amendment (A) & $*$ & $*$ & * & $*$ & $*$ & * & $*$ & * & * \\
\hline & $\mathbf{Y} \times \mathbf{A}$ & ns & * & * & * & * & * & Ns & * & * \\
\hline
\end{tabular}

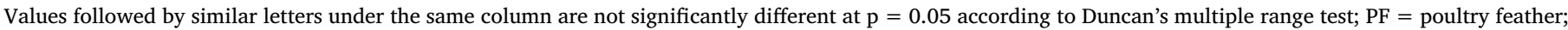
Note: *Significant difference at $\mathrm{p}=0.05$; ns, not significant at 0.05 .

increased significantly. Among Tithonia, banana, and poultry feather applied alone, poultry feather has the highest value. Among all treatments together, poultry feather + Tithonia has the best value. The interactive effect $\mathrm{Y} \times \mathrm{A}$ was significant for $\mathrm{Ca}, \mathrm{K}, \mathrm{Fe}$, and $\mathrm{Mg}$ but was not significant for $\mathrm{Cu}$.

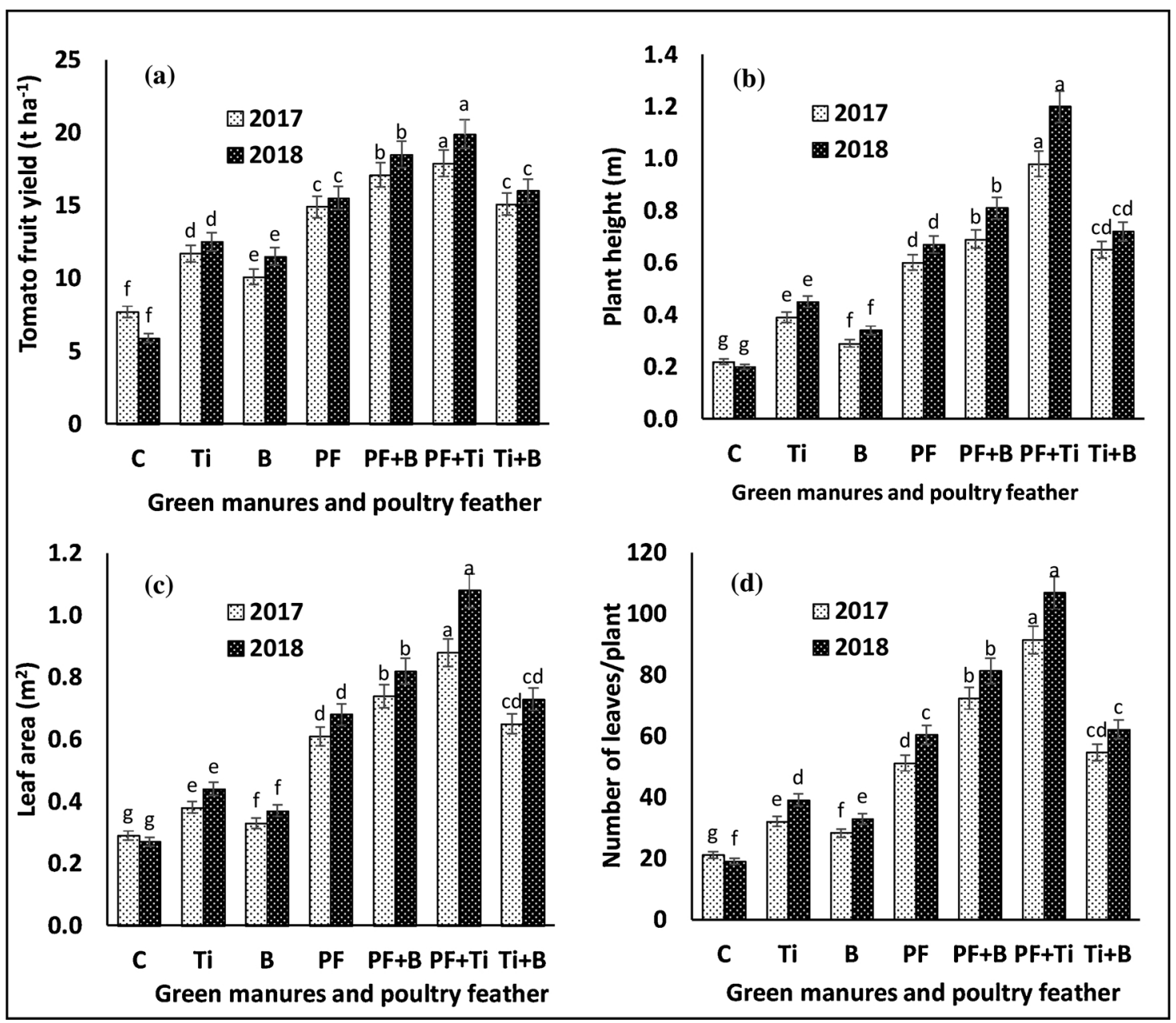

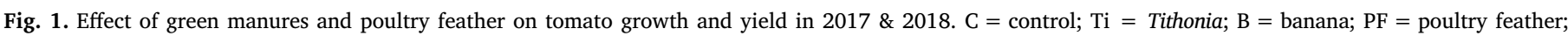

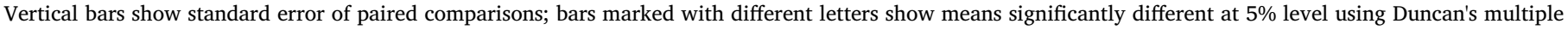
range test (For interpretation of the references to colour in this figure legend, the reader is referred to the web version of this article). 
Table 4

Effect of Green manures and poultry feather on mineral contents of tomato fruit in 2017 \& 2018.

\begin{tabular}{lllllll}
\hline Year & Amendment & Ca (\%) & K (\%) & Fe (\%) & Cu (\%) & Mg (\%) \\
\hline \multirow{2}{*}{2017} & Control & $94.6 \mathrm{f}$ & $101.6 \mathrm{f}$ & $4.5 \mathrm{~g}$ & $0.64 \mathrm{c}$ & $110.1 \mathrm{f}$ \\
& Tithonia & $133.3 \mathrm{~d}$ & $141.2 \mathrm{~d}$ & $11.4 \mathrm{e}$ & $0.68 \mathrm{bc}$ & $141.8 \mathrm{~d}$ \\
& Banana & $120.6 \mathrm{e}$ & $121.3 \mathrm{e}$ & $9.1 \mathrm{f}$ & $0.69 \mathrm{bc}$ & $121.4 \mathrm{e}$ \\
& PF & $154.2 \mathrm{c}$ & $150.6 \mathrm{c}$ & $15.5 \mathrm{c}$ & $0.70 \mathrm{ab}$ & $164.1 \mathrm{c}$ \\
& PF + banana & $174.2 \mathrm{~b}$ & $160.7 \mathrm{~b}$ & $17.4 \mathrm{~b}$ & $0.71 \mathrm{a}$ & $181.4 \mathrm{~b}$ \\
& PF + Tithonia & $195.6 \mathrm{a}$ & $184.5 \mathrm{a}$ & $20.1 \mathrm{a}$ & $0.72 \mathrm{a}$ & $192.6 \mathrm{a}$ \\
& Tithonia + banana & $156.3 \mathrm{c}$ & $151.8 \mathrm{c}$ & $13.8 \mathrm{~d}$ & $0.69 \mathrm{bc}$ & $165.1 \mathrm{c}$ \\
Control & $91.1 \mathrm{f}$ & $95.8 \mathrm{f}$ & $4.1 \mathrm{~g}$ & $0.60 \mathrm{c}$ & $104.2 \mathrm{f}$ \\
& Tithonia & $152.7 \mathrm{~d}$ & $163.3 \mathrm{~d}$ & $12.8 \mathrm{e}$ & $0.70 \mathrm{ab}$ & $161.6 \mathrm{~d}$ \\
& Banana & $132.1 \mathrm{e}$ & $147.5 \mathrm{e}$ & $10.8 \mathrm{f}$ & $0.70 \mathrm{ab}$ & $146.6 \mathrm{e}$ \\
& PF & $171.8 \mathrm{c}$ & $171.4 \mathrm{c}$ & $16.9 \mathrm{c}$ & $0.71 \mathrm{ab}$ & $186.8 \mathrm{c}$ \\
& PF + banana & $192.3 \mathrm{~b}$ & $188.3 \mathrm{~b}$ & $19.8 \mathrm{~b}$ & $0.71 \mathrm{ab}$ & $201.7 \mathrm{~b}$ \\
& PF + Tithonia & $232.1 \mathrm{a}$ & $201.1 \mathrm{a}$ & $23.6 \mathrm{a}$ & $0.73 \mathrm{a}$ & $232.3 \mathrm{a}$ \\
& Tithonia + banana & $178.9 \mathrm{c}$ & $174.7 \mathrm{c}$ & $14.9 \mathrm{~d}$ & $0.69 \mathrm{ab}$ & $188.4 \mathrm{c}$ \\
Year (Y) & $*$ & $*$ & $*$ & ns & $*$ \\
Amendment (A) & $*$ & $*$ & $*$ & $*$ & $*$ \\
Y $\times$ A & $*$ & $*$ & $*$ & ns & $*$
\end{tabular}

Values followed by similar letters under the same column are not significantly different at $\mathrm{p}=0.05$ according to Duncan's multiple range test; $\mathrm{PF}=$ poultry feather; Note: *Significant difference at $\mathrm{p}=0.05$; ns, not significant at 0.05 .

\section{Discussion}

The fairly high bulk density before the start of the experiment was partly due to its low organic matter (Adekiya and Ojeniyi, 2002). The low nutrient contents of the site before experimentation can be as a result of continuous cultivation of the soil over the years without fertilizer application. Green manures and poultry feather both sole and combined applications reduced bulk density and increased porosity of the soil compared with the control due to increase in soil organic matter (OM) from the incorporated and degraded manures by microorganisms. The presence of the green manures and poultry feather would have increased activities of beneficial soil fauna in OM decomposition which led to increased total pore space, which in turn decreased bulk density (Adekiya et al., 2019). Brady and Weil (1999) reported that the decomposition of OM from the manures produced polysaccharide which binds primary particles to become secondary particles and create larger pore spaces. The organic manures can also influence soil structural properties by enmeshing soil primary particles and microaggregates into macroaggregation through direct physical action of roots, and production of cementing agents from enhanced microbial activities. These aggregation processes and properties may reduce soil bulk density and increase porosity (Goldhamer et al., 1994; Hargrove et al., 1989; Islam and Weil, 2000). Incorporation of Tithonia diversifolia as green manure had been reported (Hafifah et al., 2016) to reduced bulk density by $27 \%$ and increased porosity by $15 \%$ compared with the initial soil (control). Also, incorporation of sunn hemp (Crotalaria juncea) in Rabi sorghum-sunflower yearly rotation cropping system was found (Guled et al., 2003) to decrease the bulk density of the soil from $1.18 \mathrm{Mg} \mathrm{m}^{-3}$ (control) to $1.0 \mathrm{Mg} \mathrm{m}^{-3}$ and increased porosity by $6.5 \%$. Likewise Chikowo et al. (2004) reported that incorporation of woody legumes into the soil reduces bulk density and increases soil granulation and porosity. The increased soil porosity and reduced bulk density with combined applications compared with sole applications was as a result of increased OM from these treatments compared to their sole forms. The improved soil physical properties of the soil in the second year relative to the first was due to the residual effect and continuous addition of the manures in the second year. There is an association between soil OM and bulk density, OM is known to be inversely related to soil bulk density (Adekiya, 2018).

Green manures and poultry feather sole or in combinations increased OM, N, P, K, Ca, and Mg compared with the control (Table 3). This revealed that these manures degraded and nutrients in them are released to the soil. Shokalu et al. (2010) found that Tithonia significantly improved $\mathrm{pH}, \mathrm{N}, \mathrm{P}, \mathrm{K}, \mathrm{Mg}$, and $\mathrm{Zn}$ contents of the soil. Banana leaves have been reported to be rich in soil nutrients (Cordeiro et al., 2004). Also, unprocessed poultry feather according to Hadas and Kautasky (1994) contains nutrients which can be added to the soil for plant uptake, they contain about $14.7 \% \mathrm{~N}$.

The higher soil nutrient concentration of poultry feather + Tithonia treatment compared with others can be as a result to the good chemical composition of both poultry feather and Tithonia (Table 2). Both have fairly good chemical composition, therefore, when poultry feather was combined with Tithonia with low C: $\mathrm{N}$ ratio, there was better / faster mineralization and nutrient release compared with their sole forms or banana with lesser quality. Adekiya (2018) reported that the quality of organic material is related to its chemical composition and C: $\mathrm{N}$ ratio.

The improved growth and yield of tomato with Tithonia, poultry feather, banana, and their combinations in this experiment compared with the control was as a result of improved soil physical (reduced bulk density and increased porosity) and chemical (OM, N, P, K, Ca and Mg) properties of the soil as a result of the incorporated green manure and poultry feather. The reduced bulk density would have enhanced better root growth and better water and nutrient uptake (Adekiya et al., 2019) and therefore better growth and yield.

Among Tithonia, banana, and poultry feather treatment alone, poultry feather has the highest values of growth and yield of tomato. This was because of reduced bulk density and increased porosity of this treatment compared to Tithonia and banana green manure treatments. Bulk density is important to water infiltration, root distribution, and root function which in turn affect nutrients and water uptake and growth. The increase in the growth and yield of tomato under poultry feather could also be as a result of the synchrony in the time of availability of sufficient amount of nutrients from the organic manures in the soil proportional with the demand of the plant uptake. Application of poultry feather at four weeks before transplanting tomato have made nutrients to be released and available at the time of need of the tomato crop. Hadas and Kaytsky (1994) reported that for unprocessed poultry feather, nutrient release are usually delayed in the first few days after application, but after four weeks nutrient release starts and continues. However, for Tithonia in this experiment, there was a scarce synchrony between soil nutrients and crop demand in that due to low $\mathrm{C}$ : $\mathrm{N}$ ratio of Tithonia, nutrients were release faster even before transplanting of tomato thereby leading to the plant not totally utilizing them, some might have even been leached before transplanting. Partey et al (2009) reported that percent dry weight remaining after the first week of decomposition of Tithonia was $20 \%$ and the highest percent of nutrients (N, P, K, Ca, and Mg) in Tithonia are released during the first week of application. Banana green manure on the other hand has inferior chemical composition (Table 2) and soil chemical composition (Table 3) compared with poultry feather and Tithonia and therefore lowest growth and yield. Furthermore, the increase in growth and yield of tomato under sole poultry feather treatment could also be due to increased $\mathrm{N}$ supply from the poultry feather relative to Tithonia and banana treatments. Based on this experiment, 10 tons of poultry feather, Tithonia, and banana green manure would have added $42.8 \mathrm{~kg} \mathrm{~N}^{-1}$, $37.5 \mathrm{~kg} \mathrm{~N} \mathrm{ha}^{-1}$, and $14 \mathrm{~kg} \mathrm{~N} \mathrm{ha}^{-1}$, respectively. Similar results were obtained by Gaskell (1999) who determined that early bell pepper (Casicum annuum L. var. annuum) yield and size were greatest in treatments with feather meal at $180 \mathrm{~kg} \mathrm{~N} \mathrm{ha}^{-1}$ when compared to treatments with the same application from compost, pelleted chicken manure, fish meal, liquid fish, liquid soybean meal or seabird guano.

Also, among all treatments, poultry feather + Tithonia has the highest value of tomato yield. This was due to improved soil physical conditions and optimum availability of soil nutrient under this treatment. In addition to improving soil physical properties, the humus of slowly decaying poultry feather may also allow retention of released nutrient from rapidly decomposing Tithonia within the rooting zone, thereby fostering greater efficiency of nutrient uptake and increase in 
Table 5

Correlation coefficient between growth and yield parameters of tomato and soil physical and chemical properties.

\begin{tabular}{|c|c|c|c|c|c|c|c|c|c|}
\hline & Soil pH & Soil OM & $\mathrm{N}$ & $\mathrm{P}$ & $\mathrm{K}$ & $\mathrm{Ca}$ & $\mathrm{Mg}$ & Bulk density & Porosity \\
\hline Yield & -0.120 & $0.789^{*}$ & $.870^{*}$ & $0.822^{*}$ & 0.372 & $0.924^{k *}$ & $0.800^{*}$ & -0.850 & $0.850^{*}$ \\
\hline Plant height & -0.119 & $0.755^{*}$ & $0.826^{*}$ & $0.815^{*}$ & 0.495 & 0.854 & $0.864^{*}$ & $-0.755^{*}$ & $0.755^{*}$ \\
\hline Leaf area & -0.070 & $0.767^{*}$ & $0.798^{*}$ & $0.768^{\prime \prime}$ & 0.356 & $0.838^{*}$ & $0.840^{*}$ & $-0.749^{*}$ & $0.748^{*}$ \\
\hline Number of leaves & -0.122 & $0.767^{*}$ & $0.758^{*}$ & $0.754^{*}$ & 0.396 & $0.816^{*}$ & $0.860^{*}$ & $-0.752^{*}$ & $0.752^{*}$ \\
\hline
\end{tabular}

* Significant difference at $\mathrm{p}=0.05$.

** Significant difference at $\mathrm{p}=0.01$.

Table 6

Correlation coefficient between some mineral contents of tomato and soil physical and chemical properties.

\begin{tabular}{|c|c|c|c|c|c|c|c|c|c|}
\hline & Soil pH & Soil OM & $\mathrm{N}$ & $\mathrm{P}$ & $\mathrm{K}$ & $\mathrm{Ca}$ & $\mathrm{Mg}$ & Bulk density & Porosity \\
\hline $\mathrm{Ca}$ & -0.180 & $0.817^{*}$ & $0.856^{*}$ & $0.835^{*}$ & 0.478 & $0.921^{*}$ & $0.843^{*}$ & -0.854 & $0.854^{*}$ \\
\hline $\mathrm{K}$ & -0.209 & $0.837^{*}$ & $0.881^{\text {** }}$ & $0.872^{*}$ & 0.587 & $0.937^{* k *}$ & $0.834^{*}$ & $-0.861^{*}$ & $0.860^{*}$ \\
\hline $\mathrm{Fe}$ & -0.103 & $0.793^{*}$ & $0.881^{\text {** }}$ & $0.877^{*}$ & 0.455 & $0.959^{* * *}$ & $0.768^{*}$ & $-0.864^{*}$ & $0.864^{*}$ \\
\hline $\mathrm{Cu}$ & -0.200 & $0.839^{*}$ & $0.843^{*}$ & $0.832^{*}$ & 0.428 & $0.927^{\text {tke }}$ & $0.751^{*}$ & $-0.928^{\text {**x }}$ & $0.928^{*}$ \\
\hline $\mathrm{Mg}$ & -0.107 & $0.765^{*}$ & $0.855^{*}$ & $0.823^{*}$ & 0.409 & $0.914^{k x k x}$ & $0.808^{*}$ & $-0.814^{*}$ & $0.814^{*}$ \\
\hline
\end{tabular}

* Significant difference at $\mathrm{p}=0.05$.

$* *$ Significant difference at $\mathrm{p}=0.01$.

yield. Greater synchronisation of nutrient supply with crop demand is considered one of the challenges facing organic resource management (Myers et al., 1994; Palm et al., 1997) and the observed differences in decomposition rate between poultry feather and Tithinia leaves may present an opportunity in that regard. Higher $\mathrm{N}$ mineralization occurs where two organic amendments were combined, compared to their sole forms, indicating a synergistic relationship between the inputs (Palm et al., 2001; Singh et al., 2007).

Therefore, tomato growth and yield in this study was dependent on soil physical and chemical properties. The positive and strong correlation between growth and yield parameters and $\mathrm{OM}, \mathrm{N}, \mathrm{P}, \mathrm{Ca}, \mathrm{Mg}$, and porosity and negative and strong correlation between these parameters and bulk density (Table 5) indicated that these soil characteristics both dictated the growth and yield of tomato in this study. Adekiya (2018) and Adekiya and Ojeniyi (2002) earlier reported that vegetable crops such as tomato react to increased soil nutrient and are also sensitive to bulk density which might influence root penetration and nutrient absorption.

The interactive effect of year and amendment $(\mathrm{Y} \times \mathrm{A})$ was significant for all growth and yield parameters, this was adduced to higher soil chemical properties in the second year of cropping tomato which is attributed to improved cation exchange capacity (Agbede et al., 2018), therefore, the improved growth and yield in the second year was due to improved nutrient availability due to residual effect from the first year and the subsequent application of the organic amendment in the second year. The addition of fresh manures to the soil in the second year may provide a fresh carbon source for microorganisms, enhancing the biological activities in the soil, and thus accelerating soil nutrient release (Xia et al., 2014), and therefore better growth and yield.

Green manures and poultry feather either as sole or combined improved the mineral contents of tomato fruits compared with the control. This was due to increased availability of nutrients due to the manures which led to increased absorption by tomato plant due to improved soil physical characteristics of the soil. Among sole incorporations, poultry feather has the highest value of $\mathrm{Ca}, \mathrm{K}, \mathrm{Fe}, \mathrm{Cu}$, and $\mathrm{Mg}$. This is consistent with the improved soil properties of this treatment. The highest value of poultry feather + Tithonia was also due to the improved chemical and physical properties of the treatment compared with others. Table 6 shows that mineral content of tomato fruit in this study was also associated with the soil physical and chemical properties. Therefore, the favourable effect of green manuring and poultry feather in this study in improving the growth, yield and mineral contents of tomato was due to better soil physical and chemical properties.
This study revealed that locally source materials in form of green manures (Tithonia and banana leaves) and poultry feather can be used in improving soil and crop productivity especially when they are combined. By these farmers in tropical countries maybe save from high cost of chemical fertilizer.

\section{Conclusion}

This study revealed that application of green manures (Tithonia diversifolia and banana leaves) and poultry feather either sole or combined reduced soil bulk density and increased porosity, SOM, nutrient content, growth, yield, and mineral contents of tomato crop compared with the control. It also revealed that Tithonia + poultry feather resulted in improved soil physical and chemical properties, and that slowly decaying poultry feather may allow retention of released nutrient from rapidly decomposing Tithonia within the rooting zone, thereby fostering greater efficiency of nutrient release, thus, better growth, yield, and mineral contents of tomato fruit. Therefore, locally source organic material can be used in improving soil and crop productivity especially when they are combined.

\section{References}

Aboyeji, C.M., Adekiya, A.O., Dunsin, O., Agbaje, G.O., Olugbemi, O., Okoh, H.O., Olofintoye, T.A.J., 2019. Growth, yield and vitamin C content of radish (Raphanus sativus L.) as affected by green biomass of Parkia biglobosa and Tithonia diversifolia. Agroforest Syst. 93, 803-812. https://doi.org/10.1007/s10457-017-0174-6.

Adekiya, A.O., Agbede, T.M., Aboyeji, C.M., Dunsin, O., Ugbe, J.O., 2019. Green manures and NPK fertilizer effects on soil properties, growth, yield, mineral and vitamin C composition of okra (Abelmoschus esculentus (L.) Moench). J. Saudi Soc. Agric. Sci. 18 (2), 218-223. https://doi.org/10.1016/j.jssas.2017.05.005.

Adekiya, A.O., 2018. Legume mulch materials and poultry manure affect soil properties, and growth and fruit yield of tomato. Agriculturae Conspectus Scientificus 83 (2), $161-167$.

Adekiya, A.O., Ojeniyi, S.O., 2002. Evaluation of tomato growth and soil properties under methods of seedling bed preparation in an Alfisol in the rainforest zone of southwest Nigeria. Soil Tillage Res. 64, 275-279.

Adene, D.F., 1997. Diseases of poultry in Nigeria: an overview of problems and solutions. Trop. Vet. 15, 103-110.

Agbede, T.M., Adekiya, A.O., Ale, M.O., Eifediyi, E.K., Olatunji, C.A., 2018. Effects of green manures and NPK fertilizer on soil properties, tomato yield and quality in the forest-savanna ecology of Nigeria. Exp. Agric. https://doi.org/10.1017/ S0014479718000376.

Akinrinde, E.A., Obigbesan, G.O., 2000. Evaluation of the fertility status of selected soils for crop production in five ecological zones of Nigeria. Proceedings of the 26th Annual Conference of the Soil Science Society of Nigeria, 279-288 (Ed. O. Babalola), 30 Oct-3 Nov.

AOAC, 2006. In: Horwitz, W., Latimer, G.W. (Eds.), Official Methods of Analysis of the Association of Official Analytical Chemists. AOAC International, 2005, 18th edn. 
AOAC International, Gaithersburg, MD.

Brady, N.C., Weil, R.R., 1999. . The nature and properties of soils. Upper Saddle River, 12th edn. Prentice-Hall, New Jersey.

Bremner, J.M., 1996. Nitrogen-total. in: Sparks DL, Editor. Methods of Soil Analysis. Part 3. Chemical Methods, $2^{\text {nd }}$ ed. ASA and SSSA, Madison (WI), pp. 1085-1121 SSSA Book Series No. 5.

Campbell, D.J., Henshall, J.K., 1991. Bulk density. In: Smith, K.A., Mullin, C.E. (Eds.), Physical Methods of Soil Analysis. Marcel Dekker, New York, pp. 329-366.

Chikowo, R., Mapfumo, M., Nyamugafat, P., Giller, K.E., 2004. Woody legume fallow productivity, biological nitrogen fixation and residual benefits to two successive maize crops in Zimbabwe. Plant Soil 262, 303-315.

Cordeiro, N., Belgacem, M.N., Torresm, I.C., Moura, J.C.V.P., 2004. Chemical composition and pulping of Banana pseudo- stems. Ind. Crops Prod. 19, 147-154.

Doran, I.B., Kaya, Z., 2003. The effect of compost prepared from banana waste material of banana plant on the nutrient content of banana leaves. J. Environ. Biol. 24, 434-444.

Frank, K., Beegle, D., Denning, J., 1998, Phosphorus. In: Brown, J.R. (Ed.), Recommended Chemical Soil Test Procedures for the North Central Region, North Central Regional Research Publication No. 221 (Revised). Missouri Agric. Exp. Station, Columbia (MO), pp. 21-26.

Gachengo, C.N., Palm, C.A., Jama, B., Othieno, C., 1999. Tithonia and senna green manures and inorganic fertilizers as phosphorus sources for maize in western Kenya. Agroforestry Sytems 44, 21-36.

Gee, G.W., Or, D., 2002. Particle-size analysis. In: Dane, J.H., Topp, G.C. (Eds.), Methods of Soil Analysis. Part 4. Physical Methods. Soil Science Society of America Book Series No. 5, Madison, WI, USA, pp. 255-293.

GENSTAT, 2005. Genstat. Release 8.1, 8th edn. VSN International Ltd, Oxford, UK.

Goldhamer, D.A., Grimes, D.W., Culick, S.H., Munk, D.S., 1994. Cover-cropped enhanced water infiltration of a slowly permeable fine sandy loam. Soil Sci. Soc. Am. J. 58, 1539-1546.

Grazziotin, A., Pimentem, F.A., deJong, E.V., Brandelli, A., 2006. Nutritional improvement of feather protein by treatment with microbial keratinase. Anim. Feed Sci Tech 126, 135-144.

Guled, M., Gundlur, S.S., Hiremath, K.A., Surakod, V.S., 2003. Influence of organic and inorganic manures on uptake of sulphur and micronutrients by rabi sorghum. Karnataka Journal of Agricultural Science 16 (2), 245-248.

Hafifah, Sudiaro, Maghfoer, M.D., Prasetya, B., 2016. The potential of Tithonia diversifolia green manure for improving soil quality for cauliflower (Brassica oleracea var. Brotrytis L.). Journal of Degraded and Mining Land Management 3 (2), 499-506.

Hargrove, W.L., McVay, K.A., Radcliff, D.F., 1989. Winter legume effects on soil properties and nitrogen fertilizer requirements. Soil Sci. Soc. Am. J. 53, 1856-1862.

Hendershot, W.H., Lalande, H., Duquette, M., 2007. Ion exchange and exchangeable cations. Soil sampling and methods of analysis. In: Carter, M.R., Gregorich, E.G. (Eds.), Canadian Society of Soil Science, 2nd ed. CRC Press, Boca Raton (Florida), pp. 197-206 Chapter 18.

Islam, K.R., Weil, R.R., 2000. Land use effects on soil quality in a tropical forest ecosystem of Bangladesh. Agric. Ecosyt. Environ. 79, 9-16.
Jama, B., Palm, C.A., Buresh, R.J., Niang, A., Gachengo, C., Nziguheba, G., Amadalo, B., 2000. Tithonia diversifolia as a green manure for soil fertility improvement in western Kenya: a review. Agrofor. Syst. 49, 201-221.

Lal, R., 1987. Management the soils of sub-saharan Africa. Science 236, 1069-1076.

Lyon, C.J., 1948. A factor method for the leaf area of tomato leaves. Plant Physiol. 23 (4), 634-635.

Morton, J.F., 1987. Banana. In: Morton, J.F. (Ed.), Fruits of Warm Climates, Florida Flair Books, Miami.

Myers, R.J.K., Palm, C.A., Cuevas, E., Guanatilleke, I.U.N., Brossard, M., 1994. The synchronisation of nutrient mineralisation and plant nutrient demand. In: Woomer, P.L., Swift, M.J. (Eds.), The Biological Management of Tropical Soil Fertility. John Wiley and Sons, Chichester, U.K, pp. 81-116.

Mawahib, E.M.E., Elfadil, A.G., Manal, F.A., BadrEldin, A.E.S., 2015. Effects of banana compost on growth, development and productivity of sorghum bicolor cultivar (Tabat). J. Adv. Biol. 8 (2), 1555-1561.

Nelson, S.C., Ploetz, R.C., Kepler, A.K., 2006. Musa species (bananas and plantains), ver. 2.2. In: Elevitch, C.R. (Ed.), Species Profiles for Pacific Island Agroforestry. Permanent Agriculture Resources (PAR), Hōlualoa, Hawai'i. http://www. traditionaltree.org.

Nelson, D.W., Sommers, L.E., 1996. Total carbon, organic carbon and organic matter. In: Sparks, D.L. (Ed.), Methods of Soil Analysis. Part 3, 2nd ed. ASA and SSSA, Madison (WI), pp. 961-1010 SSSA Book Series No. 5.

Palm, C.A., Gachengo, C.N., Delve, R.J., Cadisch, G., Giller, K., 2001. Organic inputs for soil fertility management in tropical agroecosystems: application of an organic resource database. Agric. Ecosyst. Environ. 83, 27-42.

Palm, C.A., Myers, R.J.K., Nandwa, S.M., 1997. Combined use of organic and inorganic nutrient sources for soil fertility maintenance and replenishment. In: Buresh, R.J., Sanchez, P.A., Calhoun, F. (Eds.), Replenishing Soil Fertility in Africa. SSSA Special Publication Number 51, pp. 193-217.

Shokalu, A.O., Ojo, A.O., Ezekiel-Adewoyin, D.T., Akintoye, H.A., Azeez, J.O., 2010. Evaluation of Tithonia diversifolia for soil improvement in Celosia (Celosia argentea) production. Electronic Journal of Environmental, Agricultural and Food Chemistry 9 (5), 951-957.

Singh, M., Reddy, S.R., Singh, V.P., Rupa, T.R., 2007. Phosphorus availability to rice (Oriza sativa L.)-wheat (Triticum estivum L.) in a Vertisol aft er eight years of inorganic and organic fertilizer additions. Bioresour. Technol. 98, 1474-1481.

Sonke, D., 1997. Tithonia weed - a potential green manure crop. Echo Development Notes 57, 5-6.

Stover, R.H., Simmonds, N.W., 1987. Classification of banana cultivars. In: Stover, R.H., Simmonds, N.W. (Eds.), Bananas, $3^{\text {rd }}$ edn. Wiley, New York.

Tel, D.A., Hagarty, M. (Eds.), 1984. Soil and Plant Analysis, 277. International Institute of Tropical Agriculture (IITA), University of Guelph, Ibadan, Nigeria, Guelph, Ontario, Canada.

Xia, L., Wang, S., Yan, X., 2014. Effects of long-term straw incorporation on the net global warming potential and the net economic benefit in a rice-wheat cropping system in China. Agric. Ecosyst. Environ. 197, 118-127. 